\title{
Teaching about Information Technology in Nations: Building and Using the "Landscape of IT" Repository
}

\author{
Erran Carmel \\ American University, \\ Washington, DC, USA
}

carmel@american.edu

\author{
Joan Ellen Cheney Mann \\ Old Dominion University, \\ Norfolk, VA, USA
}

\author{
imann@odu.edu
}

\section{Executive Summary}

The article describes successful learning methods for teaching about international Information Technology (IT) at two US business schools. The first case is an MBA course that, over the last eight years, built a repository of the "Landscape of IT in Nations" now used by people around the world. The second (combined Masters and BA) course has made use of this repository and introduced additional innovative learning techniques.

Building a country web site for the "IT Landscape in Nations" repository is the primary course assignment in the American University MBA class titled "Impacts of National IT Environments." The repository is found at http://www.american.edu/academic.depts/ksb/mogit/country.html The students publish the report on the web for use by educators, researchers and practitioners. There are now about 80 different nations covered in this repository. Students develop the ability to do a "country study" of IT along all of its pertinent dimensions. Since the repository is used by researchers around the world, students receive queries as "experts" on the topic. Many sites have linked to the repository and testimonials attest to its benefits. Using social exchange theory, we show that this assignment is a good motivating tool for the students.

One of the repository's regular users is the Information Systems for Global Business class at Old Dominion University (ODU) taken by undergraduate and graduate students in the Information Technology Bachelors, MBA and Computer Information Systems Masters programs. This class makes use of the repository and introduces additional innovative learning methods.

Students used the repository to learn about a nation. Then, via discussions and written assignments, they conduct comparative analyses of different nations. They rate "their" nation on its technological sophistication and benchmark that rating compared to an "ideal," compared to the USA, and compared to other nations. Such a comparative rating exposes students to information policy and national information infrastructures, as well as the role these play in how well a nation succeeds in the global environment.

Material published as part of this journal, either on-line or in print, is copyrighted by the publisher of the Journal of Information Technology Education. Permission to make digital or paper copy of part or all of these works for personal or classroom use is granted without fee provided that the copies are not made or distributed for profit or commercial advantage AND that copies 1) bear this notice in full and 2) give the full citation on the first page. It is permissible to abstract these works so long as credit is given. To copy in all other cases or to republish or to post on a server or to redistribute to lists requires specific permission and payment of a fee. Contact Editor@JITE.org to request redistribution permission.
Even more importantly, these assignments accomplish affective learning objectives that focus on changing student perspectives and behaviors. By the end of the module, students have greater awareness of the global IT environment and the competitive actions of nations within the environment.

Keywords: Global IT Education, National Information Infrastructure, National Information Policy 


\section{Introduction}

For the last seven years, MBA students at American University (Washington D.C.) have documented the landscape of IT in different nations. Their course work becomes immediately available to the world via a web-based repository (http://www.american.edu/academic.depts/ksb/mogit/country.html ). This repository has become a valuable and innovative resource for educators, researchers and practitioners.

The purpose of this paper is to describe novel but tested methods for educating students on international technology. We introduce the "Landscape of IT in Nations" project assignment and demonstrate how the assignment benefits both the student authors and those that visit the repository. To set the stage, we begin by describing the global program at American University (AU) and the course in which the Landscape of IT project is assigned. Once the academic context has been set forth, the Landscape of IT assignment is described followed by a description of the repository. To demonstrate the usefulness of the repository, we describe various audiences that have made use of the assignment. The audience we describe in detail is that of Old Dominion University (ODU) undergraduate class entitled "Information Systems for Global Business" that, for 4 years, has used the AU repository to achieve affective learning outcomes. The last portion of the paper evaluates our collective experience using learning theory perspectives. We apply social exchange theory to the AU experience and affective learning theory to ODU experience.

\section{Creating the Repository at American University}

\section{The Academic Setting: American University's MoGIT Program}

Integrating International Business and in particular International IT into the curriculum has been the source of some debate in business schools (Elliott, et al, 1994; Kaynak, 1995; Khosrowpour \& Loch, 1993). Fundamentally, we are faced with three choices (Deans \& Goslar, 1993). The choices are either to:

1. infuse the international material into the existing IT curriculum;

2. create a free-standing International IT course;

3. or, a combination of both.

At American University (Washington DC) in the Kogod School of Business, at the MBA level, we undertook the $3^{\text {rd }}$ choice and created a program labeled "Management of Global Information Technology" (MoGIT). The IT curriculum as a whole was designed to include a greater emphasis on global (and nonAmerican) perspectives. In addition, several courses were designed to be entirely international. The course described here is one of those.

\section{The Course: "Impacts of National IT Environments"}

The "IT Landscape" repository is the central learning device for the course Impacts of National IT Environments on Business. The primary objective of this half-semester course is to ensure that students fully understand how national development and IT interact to impact the functioning of both domestic and multinational organizations. A secondary objective is to make the students aware of how nations are using IT to gain comparative advantage and thus, impact the global environment. Therefore, the course exposes business students to a unit of analysis that they are usually not familiar with from other business courses- the national level. 


\section{The Repository project: "The Landscape of IT"}

The principal course project is a web-based report on the landscape of IT in a country. The report is divided into approximately 15 sections (see Figure 1). The MBA students are conducting a very broad research process: seeking data on a broad range of social science and business domains. Within each topic section the student is encouraged to gather data, statistics, and anecdotes and then interpret, integrate and evaluate these data. The typical topic section takes up 1-2 web pages. In the course of this research the students begin to grasp the intellectual landscape of ICT in a nation - what are its dimensions, its obstacles, and its potential. The students are encouraged to find policy documents (e.g., white papers) and business sources for their research.

The Impacts of National IT Environments on Business course is quick and intense. Each week students are required to prepare a draft of one assigned topic section (e.g., Telecommunications). Key course facts are presented in Figure 2.

\section{The Landscape of IT in XXX-LAND}

? Analysis: National IT strengths and weaknesses

? $\quad$ Size of domestic market

? $\quad$ National ICT Policies

? Telecommunication Infrastructure and Regulation

? $\quad$ Computing \& Internet Diffusion

? e-Commerce \& e-Business

? Domestic Production: Software Development, Hardware Mfg., and R\&D

? $\quad$ IT Workforce

? $\quad$ IT Geographics

? $\quad$ IT Financing

? $\quad$ E-Government

? $\quad$ IT Legal Environment

? $\quad$ Sources and links

? About the author

Figure 1: Web-Based Country Report Topics List (as used in Spring 2003 previous years vary somewhat)

\begin{tabular}{|l|c|}
\hline Years offered & 1995 to present (2003) \\
\hline Semesters offered & 9 \\
\hline $\begin{array}{l}\text { Number of students who have taken the } \\
\text { course (approximate) }\end{array}$ & 250 \\
\hline $\begin{array}{l}\text { Number of country projects on the } \\
\text { course web site today (approximate) }\end{array}$ & 80 \\
\hline Course duration & $\begin{array}{c}\text { Half semester, which represents 7-8 class } \\
\text { meetings of 150 minutes each. }\end{array}$ \\
\hline
\end{tabular}

Figure 2. AU Course Facts: History and Key Descriptive Data

Students are required to create a website that includes a menu with links to each of the sections of the report. A main menu is maintained by the professor with links to all the student-maintained websites. The main menu of the site is presented in Figure 3. A sample student site is presented in Figure 4. 


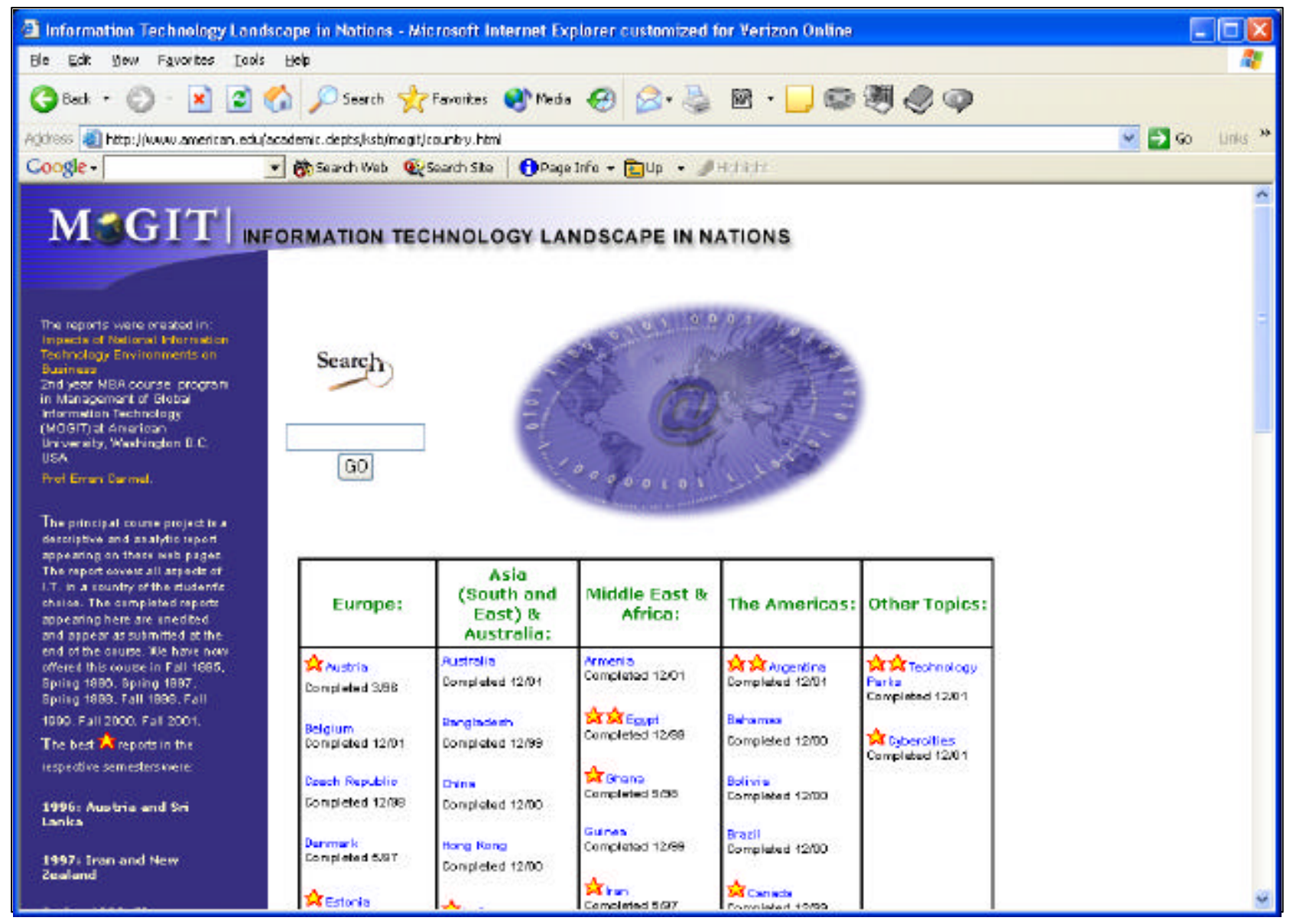

Figure 3: Homepage of Repository

http://www.american.edu/academic.depts/ksb/mogit/country.html

\section{The Repository as a Contribution to the Global Community}

The first iteration of this class in 1995 took place just as the Internet was taking off and technology globalization became a primary issue for nations and firms. This auspicious timing meant that from the outset the site was found and linked by many organizations around the world. The students' collective work now serves as an internationally recognized repository on the topic of ICT in nations. Thus, the outcome of the students' work not only serves as a vehicle for their own learning but also contributes to global knowledge.

The impact of the web-repository can be assessed by looking at the sites that have linked to it (see Figure 5). The site is visited by academics, government researchers and business researchers. 


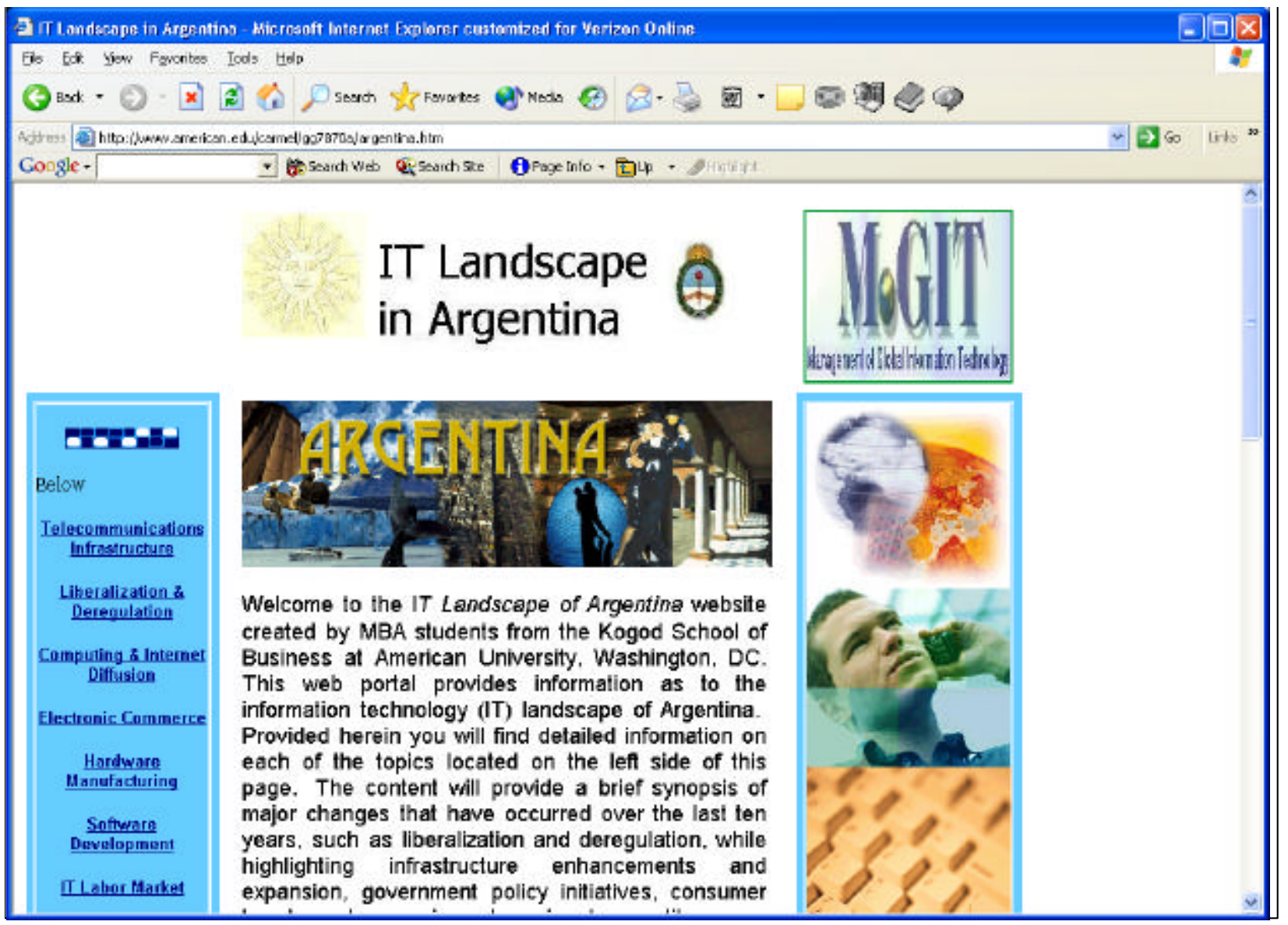

Figure 4: "Landscape of IT Report" Example

? World Bank TechNet resources

? Business 2.0 "best web links" (US business magazine)

? MERLOT (higher education data source)

? BRINT (business technology resource)

? US Dept of Commerce, Office of Technology Policy

? US Dept of Commence, National Office of Telecommunications and Information Administration - Office of International Affairs

? Babson College (USA) Horm Library

? BusinessLinc resources for small businesses

? International Economics Network

? Harvard Business School- Resources on Globalization

? University of Western Ontario Library

? LANIC - Latin America Network Information Center

Figure 5: Sites linking to the IT Landscape in Nations Repository (gathered 8/2002) 
Testimonials from the business world attest to the repository's impact. Two examples appear below. Others appear in Appendix A:

[From an UK IT Services firm] I have read your analysis of the ITC market in Italy with great interest and have found it an invaluable source of information. In particular, linking ITC trends with typical social behaviour provides an excellent insight into the challenges faced by Italian high-tech companies.[...]

[From an IT consultant in Hong Kong] My name is [...] and I am a Management Consultant at [a global IT firm] in Hong Kong. Recently, my company is commissioned by the Hong Kong government's Education and Manpower Bureau to perform a study on Information Technology (IT) Manpower and Training Needs. I have read your report on 'Information Technology in India' in American University's web site and find it very informative. It gives me a good understanding on the up-to-date IT environment in India, its strengths and weaknesses. [...].

There is also some evidence that the sections of the Landscape of IT assignment has been a contribution to global IT theory and has been a catalyst for new research:

[From an UK reader] The taxonomy of your studies, cited in the Table of Contents, is the key to my interest. While it is ambitious, your students seem to have addressed these issues well. The taxonomy is appealing because it appears sufficiently complete in trying to characterize foreign IT capabilities using metrics/issues that apply to multiple cultures. The body of information becomes a critical point of departure for specific case studies, where a case is how that IT capability may be applied to a specific application (such as an emerging technology that is dependent upon IT as a core enabling capability), even within the scope of tradeoffs such as buy-vs.-build decisions. So, the taxonomy remains relatively invariant over time and across cultures, while the information itself is subject to change. Finally, regarding the last comment, I am also interested in rates of change as an indicator for forecasting.

One of the consistent users of this repository is this article's 2nd author. Her approach and experiences are described in the next section.

\section{Using the Repository at Old Dominion University}

\section{The Academic Setting: Old Dominion University's IT Program}

Located in one of the main port cities of the US East Coast, Old Dominion University (Norfolk, Virginia, USA), has made internationalization a major focus of its mission. In the business school this mission has been accomplished by requiring every student to take a global course in order to graduate. The faculty of the IT discipline created the course that is described in this paper (see also Fi gure 6).

\begin{tabular}{|l|c|}
\hline Years offered & 1997to present (2003) \\
\hline Semesters offered & 200 \\
\hline Number of students who have taken the course & 15 Weeks \\
\hline Course Duration & 7 \\
\hline
\end{tabular}

Figure 6: ODU Course Facts: History and Key Descriptive Data

It is also noteworthy that ODU has a commitment to distance learning. This commitment coupled with the topic (communications in multinational enterprises, MNEs, is often electronic) meant that the course was designed as a web-based course. Only a few class sessions are held in the physical classroom. Most 
work involves either online chat sessions in small groups or short write-ups that are submitted via email. By the end of the course students have first-hand experience working virtually.

\section{The Course: "Information Systems for Global Business"}

The ODU course "Information Systems for Global Business" is arranged into the eight modules shown conceptually in Figure 7.

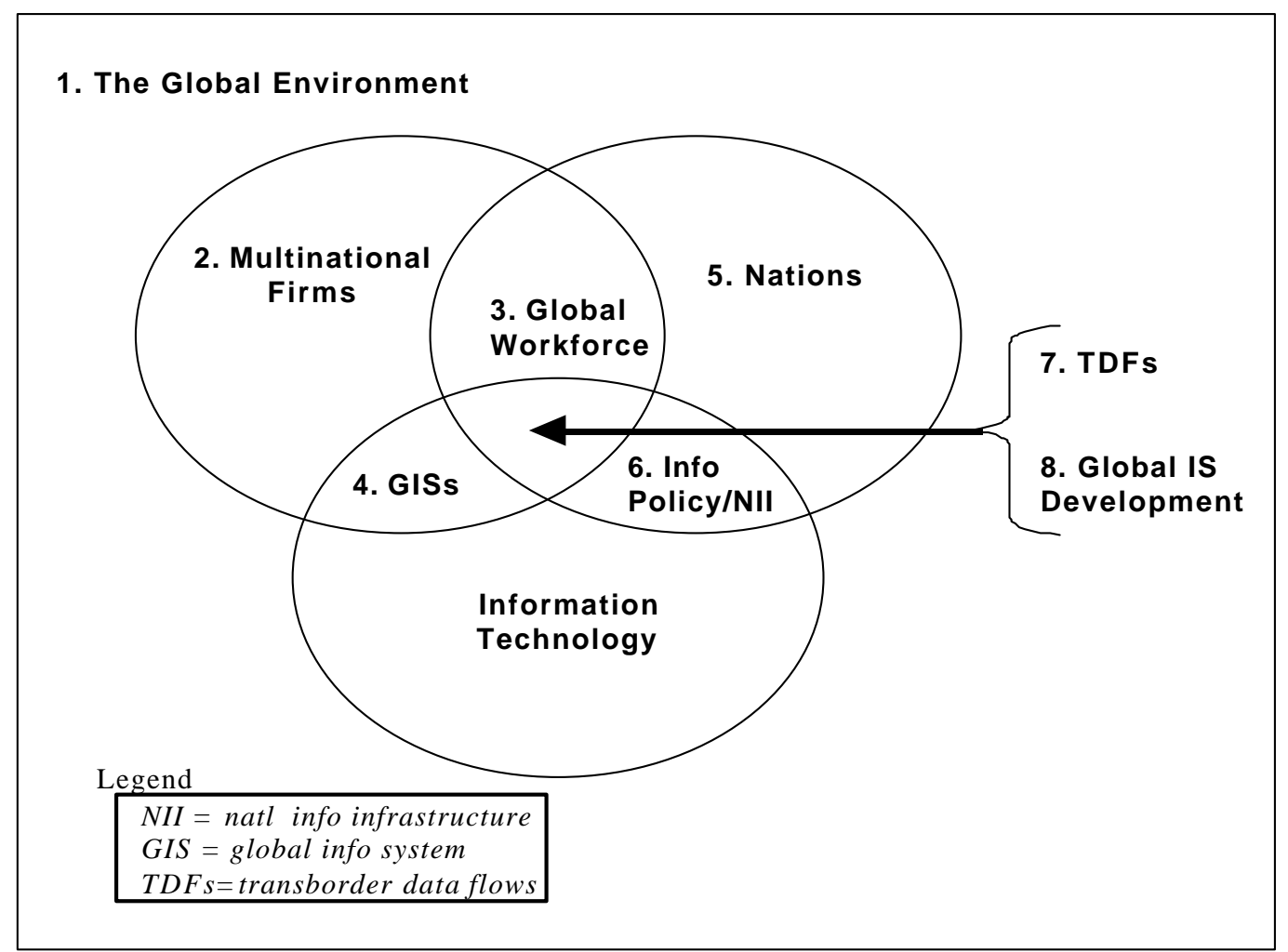

\section{Figure 7: Conceptual Structure of the ODU Course "Information Systems for Global Business."}

The "Landscape of IT" repository, created by AU students, is used in Module 6, of the course. This module has four parts depicted in Figure 8.

The AU repository is especially useful to the ODU class because it provides a condensed introduction. By using the repository, each student can quickly become familiar with a nation's ICT sophistication. While the AU students are focused on understanding the landscape, the ODU class is more focused on evaluating the level of national ICT maturity.

As part of the Module about "Nations," students are asked to select a nation from the AU repository and study that material carefully. Here, students learn that nations progress through stages of industrial development as well as stages of IT development. This sets the stage for Module 6 because it highlights the fact that nations are faced with different IT issues.

In Lesson 6.1, students learn about transportation infrastructure and then participate in an online chat in which they develop a definition of National Information Infrastructure (NII) and its components. In parallel, they read two short papers on why cities have built teleports. This lesson plan reinforces reading the AU repository reports because it highlights that a government entity (like a city or a nation) has: 1) reasons to be involved in information policy and information infrastructure development; and 2) that the information infrastructure be built with careful forethought. 
? Lesson 6.1: What is a National Information Infrastructure (NII)?

Defines the concept of an National Information Infrastructure and describes its components by comparing it to a nation's transportation infrastructure and using municipal information infrastructures to illustrate the concept

? Lesson 6.2: Information Policy

Covers the policies that nations use to address critical IT issues. Citizens of each nation should be aware of the steps that government is taking to improve the country's situation using information technology.

? Lesson 6.3: US Information Policy

Describes the ways that the US has handled information policy and NII issues. It will give US citizens a sense of whether we are on the right track.

? Lesson 6.4: IT and National Development

Covers the ways that nations, regions are using information policy to become stronger global or regional players.

\section{Figure 8: Structure of the Course Module on "Information Policy and NII."}

In Lesson 6.2 students learn about the different types of national information policies including those related to universal service, control of content, pricing issues, government use of ICT, and the role of policy in ICT education, building an ICT industry and helping domestic firms use ICT well. The assignment for this lesson has the students participating in an online chat to define what it takes for a nation to be ICT sophisticated. At the end of this module, students know the issues that nations face when formulating a national information policy. They also recognize that the national information policy may influence a nation's development and its power in the global environment.

In Lesson 6.3, each student establishes an ideal of "perfect sophistication in ICT." Then, focusing on the nation that he/she chose rates that nation on the ICT sophistication scale based on a scale from 1 to 10. Each student's ranking is then posted to a bulletin board for all to see. The students are asked to read the other nation rankings and then re-rate their nation relative to the other nations. Some students choose to compare their nation with those in the same geographic region (ex: Latin America) and others choose to compare with nations in the same level (ex: only those with low rankings). Students apply their learning by going through critical reasoning. The exercise reinforces the idea that a national policy can directly impact the comparative advantage of a nation.

In Lesson 6.4 the focus shifts to the United States. The audiotaped lecture created by the instructor for Lesson 6.3 describes the information policy and NII activities of the United States. Thus, when students are ranking their selected nations, they are also thinking about the US. Then in Lesson 6.4, the students work together in an online chat to rank the ICT sophistication of the US by comparing it to an 'ideal 10' and relative to other nations. Typically, during this chat, students realize that the US has some areas that merit national attention if the US is to maintain itself as the leading ICT power.

In the next section we use various learning theories to evaluate the pedagogical benefits of the Landscape of IT repository at AU and the use of the repository at ODU.

\section{Pedagogy: Learning Theory Applied to the Two Global IT Courses}

Teaching International topics is a challenge in any discipline because it is so amorphous.

Teaching international issues in IT to business students introduces additional challenges: the students need to quickly become fluent in a broad interdisciplinary array of issues (public policy, strategic man- 
agement, innovation management, social policy, management of global organizations, and others); students typically possess weak knowledge of these topics when they enter the classroom. In our respective courses we have developed successful methods for addressing these challenges by implicitly applying learning theory. We apply social exchange theory to the AU experience and affective learning theory to ODU experience.

\section{Pedagogical Benefits from Building the AU “Landscape of IT" Repository}

According to social exchange theory (Thibaut and Kelley, 1959), a person will agree to an exchange only if the costs of participation are low or offset by correspondingly high benefits. Social exchange theory is a particularly good fit for teaching business students who tend to be more discriminating about whether there are tangible benefits to their learning and are less interested, as a group, in abstract goals.

In the AU class, the act of displaying the reports on the public web has served as a strong incentive for students to excel. We feel that their performance is at a higher level than with a customary paper-based report to the professor at the end of the course. We note several motivational devices and outcomes in doing so.

? Awareness of impact. The students are made aware of the impact of the report repository. During the first class meeting the professor shows students testimonials from around the world regarding the site's usefulness and praising the students' work. A sample of these is displayed in the appendix.

? Higher quality due to the public nature of the repository. Making the course report public motivates the students to be more careful about their writing, fact-checking, and analysis because they recognize that the report will be available for others to see and will reflect on them and their university.

? Direct recognition of their work by others. Many students receive e-mail messages from around the world asking them, as quasi-experts, for further information about the particular country that they reported on. While most receive these messages after they are done (sometimes years after they are done), some receive them (with great pleasure) within days of setting up a draft of their report.

? Public ratings of best reports. The best reports are given "stars" as a public rating system. These ratings are similar to those that one finds on Amazon for books or eBay for good sellers. These stars are displayed on the main menu of the site. This public rating system is one that the students watch after the end of the semester when they await their grades.

? Pride in outcome via personal link to the report topic. Students are asked to select a nation with which they have an emotional attachment. The most obvious choices are those non-American students who are asked to write about their home countries. Some American students have personal ties or interests to specific countries (e.g., service in the Peace Corps, or ethnic ties). The result of this country selection process is that students develop a sense of duty to excel as representatives of that country.

? Personal responsibility by public authorship. The sense of ownership is enhanced by students adding a personal biography (publicly displayed on their report site) along with their e-mail address. One European student was tracked down to his parents' home by a manager of the incumbent national telecommunications company that was interested in hiring him based on the report that he wrote.

? Pride in artistic aspects. Design and style issues are largely left to the students to allow them creativity in web page design and to foster ownership. 


\section{Pedagogical Benefits from Using the AU Repository at ODU}

Affective learning is one of three basic categories of outcomes that are generated by pedagogical activities (Kraiger, Ford and Salas, 1993). Whereas, Cognitive Learning relates to the absorption of knowledge and Skill-Based Learning relates to competency; Affective Learning impacts the attitudes and motivations of students. Curriculum activities often have a powerful influence on student values and can even be used as socialization tools (ex: 'boot camp').

When the goal is affective learning, assignments must be created to involve the student emotionally. "Indeed, the long-held view of many teachers is that values must be caught, not taught (Rowley, et al., 2000). Thus, affective learning requires higher involvement from students and challenges them to think differently. For example, an instructor might use role-playing and storytelling to involve the student in a real-life scenario. Affective learning occurs over time as students move through different stages (receiving, responding, valuing, organization and characterization) when working through the materials assigned by the instructor (Krathwohl, Bloom and Masia, 1956). In this section, we will demonstrate how the ODU course uses the AU repository to move students through each stage of affective learning.

The first stage, Receiving, is when the learner becomes aware that a phenomenon exists in a way that makes the student wish to pay attention to it. The ODU course does this in Lesson 6.1 where students hear the lecture on infrastructure, read the article on how and why cities are building information infrastructures. It is at this point that they become aware of the concept of an information infrastructure and why it is important.

The second stage, Responding, is when the student begins to actively become involved in attending to the phenomenon of interest. In this stage the students' interest is still relatively passive, but they are involved enough to willingly follow the instructor's wishes in the assignment. In Module 6.1, the students have a discussion where they define a national information infrastructure and develop a list of its components. They use an analogy that connects an NII to a transportation infrastructure (see Figure 9) and makes it more interesting to respond to the material.

Stage 3 is Valuing, when the student is willing to admit openly that a concept has worth. Valuing is achieved in the ODU class in two ways: 1) in an online chat the students create a list of criteria for attaining perfect ICT sophistication; and 2) by having each student choose and read "Landscape of IT"

\begin{tabular}{|c|c|}
\hline Transportation Infrastructure & Information Infrastructure \\
\hline \multicolumn{2}{|c|}{ Transported Material } \\
\hline goods, products & data, multimedia, printed works \\
\hline \multicolumn{2}{|c|}{ Transporting Equipment } \\
\hline trucks, cars, planes, ships, trains & computers, web appliances, TVs, radios \\
\hline \multicolumn{2}{|c|}{ Facilities } \\
\hline terminals, ports, depots & $\begin{array}{l}\text { servers, hubs, routers, teleports, new- } \\
\text { stands, bookstores }\end{array}$ \\
\hline \multicolumn{2}{|c|}{ Connections } \\
\hline roads, highways, railroads, routes & $\begin{array}{l}\text { phone lines, fax lines, radio/light spec- } \\
\text { trum }\end{array}$ \\
\hline \multicolumn{2}{|c|}{ Support Agencies } \\
\hline commercial, governmental & $\begin{array}{l}\text { ISP's, broadcast networks, publishers, } \\
\text { NTII }\end{array}$ \\
\hline
\end{tabular}

Figure 9: Analogy Used to Promote Understanding of NII Concepts in ODU Course 
report from the AU repository. The resulting discussion forces the students to think through the role of ICT in the lives of a nation's citizens and the success of its firms.

The student begins to see the worth of an information infrastructure at the city level in Lesson 6.1. The AU repository reports reinforce the worth of information policy and information infrastructure building - but now at the national level. Every AU repository report describes the national NII and informatics policies. Students discover the role of ICT as a way for a nation to improve its global status. Valuing is evident when the students post their chosen nations ranking (on a scale of 1 to 10). Students are either impressed or disappointed with their chosen nation depending on the degree to which the nation is successful in ICT.

Organization is the fourth stage of affective learning. Organization is when students are able to apply their newly acquired values in complex ways because the values have been absorbed and integrated into the students' other values. The values have been "internalized". After the students have ranked their nation, and compared it to others, they discover that some nations are strong on some ICT dimensions while weak in others. At this point students must weigh the different ICT dimensions to determine for themselves which are more critical to their chosen nation. Their weightings are based on their own value systems and thus there is an internalization process.

The final stage of affective learning is Characterization, when the student has internalized the values to such an extent that they become part of his/her character. We see this in Lesson 6.4 in which students rate their own country -- the United States. Prior to this session many American students have a distorted view of the supremacy of the United States in ICT and its ability to maintain its global status. Now, their perspective becomes aware of other nations in a more nuanced way. Typically, the discussion begins with some students, rallying around the US (i.e. 'The US rocks!'), but then they quickly move into a more critical and balanced assessment. The demonstration of loyalty in the beginning is evidence that they know their beliefs have changed and it is a way of reconciling this new system with the old system.

Thus, Module 6 generates affective learning through the use of the AU repository. Students are not only more aware of international ICT issues, they now actively value the importance of strong national information policies and can critically evaluate a nation's effectiveness in a balanced way, including that of their own nation.

\section{Conclusion}

The repository assignment has proven to be a valuable tool for quickly introducing students to the global IT environment and motivating them to create a high quality report. The repository of reports then becomes an excellent source of information for practitioners, researchers and educators. Practitioners (including managers in multinationals and policy-makers) can use the reports to spot trends and evaluate the technological sophistication of nations. Researchers can use the repository as a gateway to sources and data, and to discover new research questions by searching for innovative initiatives in nations, or to conduct comparative analyses.

As demonstrated in the Old Dominion University example, the repository is also a valuable tool for educators. The repository can be used to promote a wider world view and achieve affective learning.

Of course, the actual landscape of IT is constantly changing. This repository represents a set of snapshots of the landscape in a fully accessible venue. The assignment that creates it, its presence on the Internet and its use by others greatly improves global IT management practice, research and teaching. 


\section{Acknowledgements}

Erran Carmel would like to thank Katherine Zettl-Schaffer, one of his students in an international IT course a decade ago for helping to formulate the focus of the course. He also thanks Felix Klimpacher, a former student in this course, for designing and helping to maintain the current version of the site.

\section{References}

Deans, C. \& Goslar, M. (1993). Alternative curriculum approaches for global IT education. In Khosrowpour, M. and Loch, K. (eds), Global information technology and education: Issues and trends. Harrisburg, PA: Idea Group Publishing.

Elliott, C. Goodwin, J. \& Goodwin, J. (1994). MBA programs and business needs: Is there a mismatch? Business Horizons, 37, 55-61.

Kaynak, E. (1995). International business teaching. Binghamton, NY: Haworth Press.

Khosrowpour, M. \& Loch, K. (1993). Global information technology and education: Issues and trends. Harrisburg, PA: Idea Group Publishing.

Kraiger, K., Ford, J. K. \& Salas, E. (1993). Application of cognitive, skill-based, and affective theories of learning outcomes to new methods of training evaluation. Journal of Applied Psychology, 78, 311-328.

Krathwal, D., Bloom, B. \& Masia, B. (1956). Taxonomy ofeducational objectives: The classification of educational goals, handbook II: Affective domains. New York: David McKay Company.

Rowley, B. (2000). Can professional values be taught? A look at residency training, Section I. Symposium: Ethics in Orthopedics, 378, 110-114.

Thibaut, J. \& Kelley, H. (1959). The social psychology of groups. New York: Wiley.

\section{Biographies}

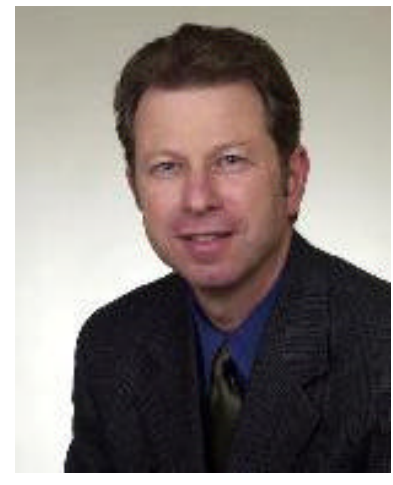

Erran Carmel is a tenured Associate Professor at American University where he co-founded and led the program in Management of Global Information Technology (MoGIT). He received his Ph.D., in Management Information Systems from the University of Arizona; his MBA from the University of California at Los Angeles, and his B.A. from the University of California at Berkeley. Prof. Carmel's area of expertise is in the management of global software development. He studies software teams, globally dispersed software teams, and offshore sourcing of IT work. His 1999 book Global Software Teams was the first on this topic. He has written over 50 publications and he consults and speaks to industry and professional groups.

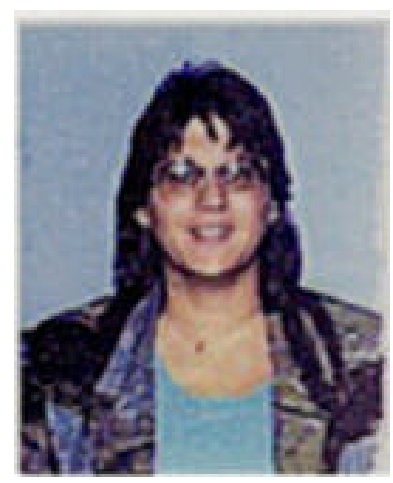

Joan Ellen Cheney Mann is an assistant professor at Old Dominion University. She holds a Ph.D. in Management Information Systems from Georgia State University. Her research generally focuses on Runaway IS projects, Global IT issues and other management of information topics. Professor Mann's research has been published in several journals, including MIS Quarterly, European Journal of Operations Research, IEEE Transactions on Engineering Management and Journal of IT Education, as well as, many national conferences including the Association for Information Systems, Academy of Management, Decision Science Institute. 


\section{Appendix 1: "Landscape of IT" Repository Testimonials}

Note: All of these e-mail quotes have been anonymized.

\section{Comments from practitioners:}

[From a Belgian consultancy] Dear Sir, I would like to congratulate you with your Website. The information is up-to-date, relevant and very practical for an ICT recruiting company like ours, having a office in every country of Europe and US. I only have one question: what about Belgium? Do you intend to ever create a report on our country? I know we are not a big country but I see one for Luxemburg and they are smaller than us! Because I would be very interested to read your analysis... I am looking forward to read your answer. Thank you for your time, have a nice day.

[From a US corporation] I am a corporate researcher who has gotten a tremendous amount of benefit from the series of graduate papers on IT Landscapes your students publish. I was hoping to find out when the next round of updates would be posted to your website, and what countries might be updated with the May, 2001 release?

[From an Asian IT consultant] Do you know any contact points in Sweden whom I can talk to? They may be representatives from related private or public organisations/industry bodies/major IT professional employers

[From a large European IT firm addressed directly to the student] $>$ Let me have pleasure of getting myself introduce to you, I am [...] . Presently working as Manager Business Development for IT > company here looking for USA \& UK market, We do have couple of projects going on software development in USA but not the major thrust in UK . > Actually i got your reference from one of the website, which mentioned that > you are MBA - and Degree in Internet Technology, I feel that you will be a great source of extended arm to us for generating a business for us and > definitely if things go fine we will take care about your Monthly expenses or we may look for other options as mutually agreed upon, we do have recently opened office in USA and we are in planning stage of opening in London. We are looking forward to hear from you positive and please let us have your feed back so that we can proceed further.

[From a US student] I am finishing my MBA at the USC Marshall School of Business and I want to tell you what a useful resource that your students' reports are. I am working on a project for 3Com right now and [student's name] report was very helpful to us. We will certainly cite her in our sources list! I was pleasantly surprised to see this type of caliber of research being published on the internet by an MBA program. Our program also does extensive international research on different markets, including IT, but most of it is confidential and can't be published. It's too bad, as it is good publicity.

[From a reader in Brazil] I happened to stumble over the web site created by your class when I was looking for info regarding IT in Brazil. I was very impressed to all of that work that you and your group did. Also, I especially wanted to congratulate [...] on her Brazilian site.

[From a US student] I'm a graduate student at Carnegie Mellon University's, The Heinz School and I just wanted to let you know that the work your students have done in the class Impacts of National Information Technology Environments on Business is very impressive.

\section{Quotes from students}

[From a former student] I just wanted to let you know that even though at the beginning I was extremely doubtful of the usefulness of the IT landscape project on Romania, I did receive a couple of emails from Romania stating that they used the data found on that class menu. It seems that there is a total lack of 
information about the Romanian IT economy on the web. Thank you for encouraging me to take on that project and helping me with those leads.

[From a former student] I received 2 e-mails from Australia and Egypt regarding the project on IT in India. One was from a student in Australia who is doing his honors thesis in Global Software development (Global Outsourcing) and the other was from a Prof in an University in Egypt who is doing research work on IT in different nations. They had queries regarding IT in India, which I was more then happy to respond to. They also commented that the structure of the projects was applaudable, which of course the credit goes to you. I have recommended them to go through the other projects (different nations) for more information on IT in different countries. I think it's a wonderful academic project over the web. It's a great feeling to share one's knowledge with people all over the world. 